\title{
LEMBAGA ADAT DI KASEPUHAN CIPTA MULYA DESA SINAR RESMI KECAMATAN CISOLOK KABUPATEN SUKABUMI PROUINSI JAWA BARAT
}

\author{
Oleh Ria Andayani Somantri
}

Balai Pelestarian Sejarah dan Nilai Tradisional Bandung

Jln. Cinambo No. 136 Ujungberung Bandung

Email: riaandayanisomantri@yahoo.com

\begin{abstract}
Abstrak
Penelitian tentang Lembaga Adat di Kasepuhan Cipta Mulya, Kampung Cipta Mulya, Desa Sinar Resmi, Kecamatan Cisolok, Kabupaten Sukabumi, Provinsi Jawa Barat bertujuan untuk mengetahui hal yang mendasari lembaga adat itu terbentuk,termasukjuga struktur lembaga adat Kasepuhan Cipta Mulya. Penelitian tersebut bersifat deskriptif analisis dengan pendekatan kualitatif. Data yang dikumpulkan terdiri atas data primer dan data sekunder. Data primer diperoleh dengan teknik pengamatan; dan wawancara mendalam kepada sejumlah informan, yang ditentukan melalui metode snowballing. Data sekunder didapat melalui studi literatur yang digunakan untuk menganalisis masalah dalam penelitian. Hasil penelitian menunjukkan bahwa lembaga adat di Kasepuhan Cipta Mulya mengacu pada aturan-aturan warisan leluhurnya yang terkristalkan dalam lembaga adat yang disebut kasepuhan. Struktur organisasi lembaga adat kasepuhan tergambarkan dalam hierarki yang didasarkan pada penguasaan tentang adat isitiadat setempat. Hierarki tersebut terdiri atas ketua adat, baris sesepuh, dan warga Kasepuhan Cipta Mulya.
\end{abstract}

Kata kunci: lembaga adat, kasepuhan, Cipta Mulya

\section{Abstract}

This research aims to investigate the reason for the establishment of this institution, including its structure. This is a descriptive-analytical research using qualitative approach. The author compiled primary and secondary data as well. Primary data are obtained through observation and in-depth interview with some informants using snowballing method. Bibliographic study is conducted to get secondary data to analyse research question. The result is, that the customary 
institution in Kasepuhan Cipta Mulya is referred to the rules inherited from their ancestors and crystallized in the form of customary institution called kasepuhan. The structure of the Kasepuhan is based on the ability of person in mastering adat (custom) rules. Hierarchically, it consists of ketua adat (the chief), baris sesepuh (the elders), and warga (the people) of Kasepuhan Cipta Mulya.

Keywords: customary institution, kasepuhan, Cipta Mulya

\section{A. PENDAHULUAN}

Pada hakikatnya, manusia merupakan makhluk sosial, yang senantiasa memerlukan manusia lain untuk memenuhi berbagai kebutuhan hidupnya. Sejak lahir, dia memiliki naluri untuk menjadi satu dengan individu-individu lain di sekelilingnya dan menyatu dengan suasana alam di sekitarnya. Melalui naluri yang paling mendasar itulah terbentuksuatu kesatuan hidup manusia yang berinteraksi menurut suatu sistem adat istiadat tertentu yang bersifat kontinyu, dan yang terikat oleh suatu rasa identitas bersama. Kesatuan hidup manusia seperti itu dinamakan masyarakat (Fadjria, 2004:3).

$\mathrm{S}$ is te m kemasyaratan diIndonesia, umumnya mengacu pada tatanan aturan yang berada dalam kerangka Negara Kesatuan Republik Indonesia. Meskipun demikian, tidak berarti hal itu menafikan keberadaan tatanan aturan lokal yang diwariskan oleh nenek moyang suatu kelompok masyarakat. Bahkan, ada di antaranya yang lebih dominan mengatur kehidupan suatu masyarakat dibandingkan dengan aturan yang bersifat formal. Aturan tersebut biasanya terkristalkan dalam suatu lembaga yang dikenal dengan sebutan lembaga adat.

Lembaga adat adalah sebuah organisasi sosial kemasyarakatan, baik yang sengaja dibentuk maupun yang secara wajar telah tumbuh dan berkembang di dalam sejarah masyarakat yang bersangkutan atau dalam suatu masyarakat hukum adat tertentu dengan wilayah hukum dan hak atas harta kekayaan di dalam wilayah hukum adat tersebut serta berhak dan berwenang untuk mengatur, mengurus, dan menyelesaikan berbagai permasalahan yang berkaitan dengan dan mengacu pada adat istiadat dan hukum adat yang berlaku (BPSNT Bandung, 2001:7).

Berbicara mengenai lembaga adat tentu tidak akan lepas dari konsep tentang struktur sosial. Struktur sosial atau dalam istilah asing biasa disebut social structure adalah suatu jaringan (abstrak) yang mengatur hubungan orang dengan orang di dalam kehidupan masyarakat dalam suatu sistem sosial tertentu (Adimiharja, 1976:18). Struktur sosial biasanya meliputi dasar-dasar keluarga, perkawinan, sistem kekerabatan, status dan peranan sosial, stratifikasi sosial, himpunan yang didasarkan pada kelompok usia dan keturunan, organisasi sosial, kesemuanya itu baik yang dianut masyarakat yang masih sederhana tingkat kebudayaannya, maupun oleh masyarakat yang modern. Sementara itu R.Firth (Minanda, 1981:25) melihat struktur sosial suatu masyarakat itu terdiri atas dua bagian besar, yaitu kelompokkelompok sosial atau kesatuan-kesatuan sosial, dan lembaga-lembaga sosial.

Keberadaan suatu kelompok masyarakat yang masih menempatkan 
lembaga adat sebagai pedoman untuk mengatur kelangsungan hidup mereka perlu mendapat perhatian serta penting untuk diidentifikasi. Bagaimanapun juga, bukan hal mudah bagi mereka untuk mempertahankan lembaga adat dalam dinamika perkembangan zaman. Dasar pemikiran tersebut menjadi latar belakang dilakukannya penelitian tentang lembaga adat pada suatu kelompok masyarakat. Penelitian tersebut berjudul Lembaga Adat di Kasepuhan Cipta Mulya, Kampung Cipta Mulya, Desa Sinar Resmi, Kecamatan Cisolok, Kabupaten Sukabumi.

Masalah penelitian dinyatakan dalam dua pertanyaan penelitian, yaitu:

1. Apakah yang mendasari lembaga adat di Kasepuhan Cipta Muya?

2. Bagaimanakah wujud strukturlembaga adat di Kasepuhan Cipta Mulya?

Adapun tujuan penelitian tersebut adalah untuk mengetahui hal-hal yang mendasari lembaga adat di Kasepuhan Cipta Mulya dan struktur organisasi lembaga adat di Kasepuhan Cipta Mulya.

Ruang lingkup penelitian meliputi dua hal yakni wilayah dan materi. Ruang lingkup wilayah penelitian adalah Kampung Cipta Mulya, Desa Sinar Resmi, Kecamatan Cisolok, Kabupaten Sukabumi, Provinsi Jawa Barat. Wilayah tersebut dipilih karena merupakan pusat Kasepuhan Cipta Mulya; dan ruang lingkup materi penelitian meliputi gambaran umum Kampung Cipta Mulya dan lembaga adat di Kasepuhan Cipta Mulya berikut struktur organisasinya.

Metode penelitian yang digunakan bersifat deskriptif analisis. Penelitian deskriptif bertujuan menggambarkan secara tepat sifat-sifat suatu gejala sosial, baik individu-individu, kelompok- kelompok, dan keadaan sosial tertentu. Oleh karena itu, pendekatan yang sesuai untuk jenis penelitian deskriptif adalah pendekatan kualitatif. Data yang dikumpulkan terdiri atas data primer dan data sekunder. Data primer diperoleh dengan teknik pengamatan; dan wawancara mendalam kepada sejumlah informan, yang ditentukan melalui metode snowballing. Data sekunder didapat melalui studi literatur yang digunakan untuk menganalisis masalah dalam penelitian.

\section{B. HASIL DAN BAHASAN}

Kasepuhan Cipta Mulya, secara administratif terdapat di Kampung Cipta Mulya, Desa Sinar Resmi, Kecamatan Cisolok, Kabupaten Sukabumi, Provinsi Jawa Barat. Kasepuhan Cipta Mulya menunjuk pada satu kesatuan sosial yang warganya terikat oleh adat istiadat tertentu yang khas. Adat istiadat tersebut terkristalkan dalam satu lembaga adat yang disebut kasepuhan. Oleh karena itu, warga Kasepuhan Cipta Mulya dapat dikategorikansebagaisalahsatukomunitas adat yang terdapat di wilayah Kabupaten Sukabumi, Provinsi Jawa Barat. Selain itu, Kasepuhan Cipta Mulya merupakan bagian dari Kesatuan adat Banten Kidul, bersama sejumlah kasepuhan lainnya yang tersebar di wilayah Provinsi Jawa Barat dan Banten.

Warga Kasepuhan Cipta Mulya menetap di Kampung Cipta Mulya dan di sejumlah kampung lainnya. Yang mengikat mereka sebagai warga Kasepuhan Cipta Mulya adalah keyakinan untuk mengikuti adat istiadat Kasepuhan Cipta Mulya. Ada beberapa faktor yang melatarbelakangi mereka menetapkan hati seperti itu. Pertama, mereka 
melakukan hal tersebut untuk memenuhi amanat orang tua dan leluhurnya agar senantiasa menjadi bagian dari komunitas adat Kasepuhan Cipta Mulya. Kedua, mereka melakukannya karena ada kecocokan dengan adat istiadat Kasepuhan Cipta Mulya, terutama dalam masalah pertanian. Saat ini, ada sekitar 12.383 jiwa tercatat sebagai warga Kasepuhan Cipta Mulya, yang terbagi menjadi 2.203 kepala keluarga.

Pusat Kasepuhan Cipta Mulya berada di Kampung Cipta Mulya, Desa Sinar Resmi, Kecamatan Cisolok, Kabupaten Sukabumi, Provinsi Jawa Barat.Dikatakan sebagaipusatkasepuhan, karena di wilayah itu menetap pemimpin atau ketua adat Kasepuhan Cipta Mulya. Dia tinggal di satu rumah yang disebut imah gede. Lokasi imah gede berada di RT 07. Kampung itu menempati wilayah RT 07 dan RT 05.

Kampung Cipta Mulya dihuni oleh warga Kasepuhan Cipta Mulya yang berjumlah sekitar 40 kepala keluarga. Mereka tinggal di rumahrumah tradisional yang khas. Karena kekhasan itulah, Kampung Cipta Mulya juga dapat dikatagorikan sebagai kampung adat. Sementara itu, warga Kasepuhan Cipta Mulya lainnya tinggal di sejumlah kampung lainnya. Sekalipun mereka menetap di luar Kampung Cipta Mulya dan berbaur dengan warga setempat, mereka tetap menginduk pada adat istiadat yang berlangsung di pusat Kasepuhan Cipta Mulya.

Kehidupan yang berlangsung di pusat Kasepuhan Cipta Mulya mengacu pada tata aturan lama yang diwariskan leluhurnya sejak dulu. Aturan tersebut berupa lembaga adat yang biasa disebut kasepuhan. Dengan demikian, sistem kemasyarakatan di
Kasepuhan Cipta Mulya ditentukan oleh lembaga adat tadi. Lembaga adat tersebut mengatur kedudukan seseorang dalam kehidupan sehari-hari, berikut hak dan kewajibannya. Dalam lembaga adat Kasepuhan Cipta Mulya terdapat struktur organisasi tradisional yang mengacu pada penguasaan adat istiaat setempat. Struktur tersebut ditempati oleh ketua adat, sejumlah pejabat adat yang tergabung dalam satu kelompok yang disebut baris sesepuh, dan warga masyarakat.

Sejumlah kedudukan yang terdapat dalam struktur lembaga adat Kasepuhan Cipta Mulya adalah sebagai berikut:

\section{Ketua Adat}

Ketua adat merupakan jabatan tertinggi dalam struktur lembaga adat Kasepuhan Cipta Mulya, sekaligus juga menjadi pemimpin di kasepuhan tersebut. Tidak sembarang orang dapat memiliki kedudukan tertinggi di tempat itu, karena ada kriteria yang harus dipenuhi. Seorang ketua adat harus laki-laki dan memiliki hubungan darah dengan ketua adat sebelumnya. Dengan demikian, jabatan ketua adat diteruskan secara turun-temurun. Jika dia tidak memiliki anak laki-laki, jabatan ketua adat selanjutnya akan jatuh kepada adik atau kakak dari ketua adat.

Jabatan ketua adat saat ini sudah mencapai generasi ketujuh, jika dilihat darisilsilahnya. Sekalipundemikian, tidak semua nama ketua adat masih menempel dalam ingatan warga Kasepuhan Cipta Mulya. Mereka hanya mampu mengingat nama ketua adat dari generasi kelima hingga ketujuh. Nama-nama tersebut secara berurutan adalah Ama Jasium, Ama Rusdi, Ama Arjo, dan Ama Uum. 
Dua nama yang disebut terakhir masih satu generasi, karena mereka merupakan kakak beradik.

Nama yang disebutkan terakhir adalah ketua adat Kasepuhan Cipta Mulya sekarang. Baru tujuh tahun dia menjabat sebagai ketua adat, dengan nama dan pusat kasepuhan yang berbeda. Dua tahun pertama, dia menjabat sebagai ketua adat Kasepuhan Sirnaresmi dengan pusat kasepuhannya di Kampung Sinaresmi; dan lima tahun berikutnya, dia menduduki jabatan sebagai ketua adat Kasepuhan Cipta Mulya dengan pusat kasepuhannya di Kampung Cipta Mulya.

Perubahan tersebut terjadi setelah ketua adat sebelumnya, Ama Arjo meninggal. Pada saat itu dia menjabat sebagai ketua adat Kasepuhan Sirna Resmi, yang berpusat di Kampung Sinar Resmi. Setelah dia meninggal, terjadi dualisme kepemimpinan di Kasepuhan Sirna Resmi. Ada dua persepsi berbeda yang melatarbelakangi hal tersebut.

Versi pertama, pandangan sekelompok orang yang mengatakan bahwa yang berhak naik tahta menjadi ketua adat selanjutnya adalah anak laki-laki dari ketua adat yang telah meninggal. Oleh karena itu, kelompok tersebut memilih anak ketua adat yang lama untuk meneruskan kepemimpinan di Kasepuhan Sirna Resmi.

Versi kedua, pandangan sekelompok orang yang menyatakan bahwa jabatan ketua adat harus dikembalikan kepada kakak dari ketua adat yang meninggal. Konon, dulu yang seharusnya menjadi ketua adat adalah kakaknya, karena dia merupakan anak laki-laki Ama Rusdi yang paling besar. Karena satu dan lain hal, dia tidak menerima jabatan tersebut. Akhirnya jabatan ketua adat diteruskan oleh adiknya sampai meninggal. Setelah adiknya meninggal, dia merasa terpanggil kembali untuk memenuhi kewajiban adat yang pernah ditawarkan kepadanya, yakni menjadi ketua adat Kasepuhan Sirna Resmi. Kelompok yang berpandangan seperti itu akhirnya menjadi pengikut dia.

Kedua pandangan berbeda itu ternyata tidak dapat dikompromikan menjadi keputusan yang melahirkan satu ketua adat di Kasepuhan Sirna Resmi. Kedua kelompok tersebut tetap pada keyakinannya masing-masing. Pada akhirnya, di kasepuhan terjadi dualisme kepemimpinan dengan pengikutnya masing-masing. Anak laki-laki ketua adat yang meninggal menjadi ketua adat bagi warga Kasepuhan Sirna Resmi yang menginduk kepadanya. Bersamaan dengan itu, kakak dari ketua adat yang meninggal juga menjadi ketua adat bagi warga Kasepuhan Sirna Resmi yang menginduk kepadanya. Kondisi demikian berjalan selama 2 tahun, sejak 1993 hingga suatu saat terjadi kebakaran di Kampung Sinar Resmi, yakni pada 1995. Kebakaran tersebut menghabiskan sebagian besar rumah-rumah penduduk.

Ketua adat yang dipegang oleh anak ketua adat yang lama bersamasama pengikutnya membangun kembali puing-puing rumah yang hancur karena kebakaran. Tidak demikian halnya dengan ketua adat yang dipegang oleh kakak ketua adat yang lama. Dia bersama pengikutnya tidak sibuk mendirikan rumah baru untuk tempat tinggal mereka, karena ternyata dia mendapat wangsit 'petunjuk dari leluhur yang datang melalui mimpi' agar memindahkan pusat kasepuhan yang dipimpin olehnya ke tempat yang baru. 
Wangsit dari leluhur merupakan sesuatu yang harus dilaksanakan. Jika tidak, dia takutdibendon 'akan mengalami hal-hal yang tidak baik bagi dirinya juga pengikutnya'. Atas dasar itulah, dia segera mencari lahan baru untuk dibuka menjadi pusat kasepuhan. Lahan tersebut harus memadai luasnya, karena di tempat itu akan didirikan sejumlah bangunan untuk tempat tinggal juga berbagai fasilitas adat lainnya. Lahan yang dimaksud tidak jauh dari Kampung Sinar Resmi, dan diberi nama Kampung Cipta Mulya. Nama Cipta Mulya digunakan berdasarkan wangsit, dengan harapan agar kampung dan masyarakatnya senantiasa berada dalam kamulyaan 'kemuliaan'.

Setelah semua fasilitas yang diperlukan bagi kelangsungan sebuah pusat kasepuhan tersedia, kakak dari ketua adat yang meninggal segera memutuskan untuk pindah dari Kampung Sinar Resmi. Dia bersama 35 orang pengikut setianya menempati kampung baru yang bernama Kampung Cipta Mulya. Nama kasepuhan yang dipimpin oleh dia pun diganti menjadi Kasepuhan Cipta Mulya. Pada akhirnya, perpindahan pusat kasepuhan yang berlangsung pada 1995 itu mengakhiri dualisme kepemimpinan bagi Kasepuhan Sirna Resmi. Kedua ketua adat tersebut telah memiliki wilayah kekuasaan dan pengikutnya masing-masing dengan nama kasepuhan yang berbeda pula.

Ketua adat Kasepuhan Cipta Mulya mengemban sejumlah kewajiban yang harus dilaksanakan secara konsisten. Pertama, dia memiliki kewajiban utama menjaga kelangsungan adat istiadat yang diwariskan leluhurnya, yang tercermin dalam berbagai aspek kehidupan. Oleh karena itu, secara adat dia berhak memimpin semua aktivitas yang berkaitan dengan adat istiadat setempat, baik yang dilaksanakan secara kolektif maupun individu.

Kedua, dia berkewajiban menjadi pemimpin bagi seluruh warga Kasepuhan Cipta Mulya, baik yang tinggal di dalam dan di luar Kampung Cipta Mulya. Oleh karena itu, dia senantiasa melayani warga kasepuhan yang datang meminta restu kepadanya untuk berbagai kepentingan, dan meminta bantuan untuk mengatasi berbagai persoalan yang dihadapi oleh warganya. Restu ketua adat identik dengan restu dari leluhur, karena ketua adat merupakan perwakilan leluhur di dunia.

Ketua adat bersama keluarganya tinggal di pusat Kasepuhan Cipta Mulya dalam sebuah bangunan yang disebut imah gede. Selain sebagai tempat tinggal ketua adat, imah gede juga menjadi tempat pelaksanaan berbagai aktivitas adat dan tempat menerima warga kasepuhan yang ingin menemui ketuanya. Di tempat tersebut, dia dikelilingi oleh baris sesepuh yang terdiri atas sejumlah pejabat adat dan para pembantunya. Mereka terdiri atas kolot lembur, dukun,gandek, bengkong, paraji ngalahirkeun, paraji panganten, pamoro, panghulu, amil, kemit, giliran, sabah, dan rendangan. Mereka mendapat tugas dari ketua adat sesuai dengan garis keturunannya, dan melaksanakan tugasnya masingmasing agar kelangsungan kehidupan ketua adat dan warganya dapat berjalan sebagaimana mestinya sesuai koridor adat istiadat yang berlaku.

\section{Baris Sesepuh}

Tidak setiap orang dapat menjadi anggota baris sesepuh, karena semua sudah ada ketentuannya. Semua jabatan 
adat yang terdapat dalam baris sesepuh diperoleh secara turun temurun, dan harus mendapat legitimasi dari ketua adat. Jika seseorang mendapat pesan, baik secara langsung atau tidak langsung dari orang tua agar menggantikan kedudukannya dalam jabatan adat tertentu, itu diyakini sebagai kepercayaan dari leluhur. Dia tidak dapat menolaknya, karena kemanapun dia pergi, panggilan itu pada saatnya akan tetap datang. Oleh karena itu, sudah semestinya pesan tersebut dilaksanakan oleh yang bersangkutan.

Jika orang tersebut berupaya menolak atau menghindari jabatan tersebut, ketua adat tidak akan menegurnya. Dia akan merasakan sendiri hal-hal yang kurang baik dalam kehidupannya atau disebut kabendon. Ada kemungkinan dia dan anggota keluarganya akan mendapat musibah, geyengan 'menderita satu penyakit yang berkepanjangan', atau sering mendapat kesulitan. Oleh karena itu, pewarisan jabatan adat harus diterima dengan keikhlasan hati sebagai suatu bentuk pengabdian. Apapun jabatan adat yang didudukinya, mereka percaya pasti ada rizkinya.

Setiap jabatan adat tentu akan disertai dengan sejumlah kewajiban yang harus dilaksanakan dengan baik dan penuh tanggung jawab. Selain kewajiban, di dalamnya juga terdapat aspek hak-hak yang akan diterimanya terkait dengan jabatan tersebut. Salah satu hak yang akan diterima para pejabat adalah pemberian tunjangan berupa padi dalam jumlah tertentu setiap periode waktu tertentu pula. Untuk jabatan adat tertentu, tak jarang mereka menerima imbalan dari warga kasepuhan atas jasanya membantu warga Kasepuhan Cipta Mulya. Jabatan- jabatan adat yang termasuk dalam baris sesepuh adalah sebagai berikut.

\section{a. Kolot Lembur}

Warga Kasepuhan Cipta Mulya tidak hanya tinggal di Kampung Cipta Mulya, melainkan tersebar di sejumlah kampung lain. Di setiap kampung yang terdapat warga Kasepuhan Cipta Mulya, termasuk di Kampung Cipta Mulya sendiri, dipastikan ada seseorang yang ditunjuk sebagai kolot lembur oleh ketua adat. Kolot lembur merupakan wakil ketua adat di kampung tersebut. Oleh karena itu, dia harus laki-laki dan menguasai adat istiadat Kasepuhan Cipta Mulya. Selain itu, dia juga biasanya merupakan keturunan kolot lembur sebelumnya. Dalam kesehariannya, dia merupakan kepanjangan tangan ketua adat di setiap kampung. Selain itu, dia juga menjadi perantara bagi ketua adat dan warganya.

Jika ketua adatakanmenyampaikan informasi tentang aktivitas adat kepada warganya, dipastikan akan dilakukan melalui kolot lembur, yang jumlahnya diperkirakan mencapai 30 orang. Mereka biasanya dikumpulkan di imah gede agar mendapat informasi dalam waktu yang bersamaan. Kesempatan itu juga digunakan para kolot lembur untuk menyampaikan aspirasi warga kampungnya masing-masing kepada ketua adat. Hasil pertemuan itu akan disampaikan kembali oleh kolot lembur kepada warga Kasepuhan Cipta Mulya di kampungnya masing-masing. Pertemuan seperti itu paling sedikit dilakukan 10 (sepuluh) kali dalam satu tahun, di antaranya ketika akan memulai seluruh tahapanaktivitaspertanian, melaksanakan 
sejumlah upacara tradisional, dan hendak kerja bakti.

Setiap kolot lembur membawahi rendangan 'satu kesatuan keluarga yang berasal dari satu keturunan yang sama'. Setiap rendangan biasanya beranggotakan lebih dari satu keluarga. Jumlah rendangan yang dipimpin oleh ketua adat tidak sama. Ada kolot lembur yang hanya membawahi 5 rendangan, dan ada pula kolot lembur yang memimpin rendangan hingga 200 rendangan.

\section{b. Dukun}

Manusia tidak selamanya dapat mempertahankan kebugaran kondisi tubuhnya. Karena satu dan lain hal, mungkin saja dia jatuh sakit. Bagi warga Kasepuhan Cipta Mulya, kondisi sakit seseorang tidak hanya menyangkut aspek fisik, melainkan juga ada aspek lainnya di luar hal itu. Mereka percaya, seseorang juga bisa sakit karena ada kekuatan gaib yang mengganggu atau menyerangnya. Kekuatan gaib itu bisa datang dari makhluk gaib yang merasa terganggu, makhluk gaib yang memang ingin mengganggu, atau kiriman dari manusia yang memanfaatkan kekuatan gaib untuk tujuan tertentu. Dengan demikian, tidak hanya aspek medis yang diupayakan untuk menyembuhkan orang sakit, seperti pergi ke dokter atau mengkonsumsi obat bebas yang tersedia di sejumlah warung. Selain itu, upaya nonmedis pun dilakukan dengan menjalani pengobatan tradisional oleh dukun Kasepuhan Cipta Mulya.

Keberadaan dukun dalam kehidupan warga Kasepuhan Cipta Mulya sangat penting. Dukun sendiri merupakan jabatan adat yang terdapat dalam struktur lembaga adat Kasepuhan
Cipta Mulya. Jabatan tersebut biasanya diperoleh secara turun temurun dan jatuh kepada anak laki-laki. Legalitas seorang dukun diperoleh melalui pengangkatan dan pengukuhan oleh ketua adat. Jumlah dukun yang terdapat di Kasepuhan Cipta Mulya hanya ada satu. Dia memegang jabatan tersebut sampai meninggal atau selama dibutuhkan oleh ketua adat dan warga Kasepuhan Cipta Mulya. Sekalipun demikian, dia dapat berhenti menjadi dukun jika dia merasa tidak mampu lagi melaksanakan tugasnya sebagai dukun, karena alasan sakit misalnya.

Seorang dukun mendapat sejumlah tugas dari ketua adat. Pertama, dia memilki kewajiban untuk menjaga kehidupan warga Kasepuhan Cipta Mulya dari berbagai gangguan kekuatan gaib. Wujud gangguan tersebut biasanya berupa penyakit. Untuk mengatasinya perlu upaya perdamaian antara manusia dan kekuatan gaib tersebut. Upaya itulah yang dilakukan oleh seorang dukun Kasepuhan Cipta Mulya.

Pengobatan yang dilakukan oleh dukun terhadap warga yang sedang sakit lazim disebut disareatan. Dalam hal ini, dia memiliki kemampuan untuk berkomunikasi dengan berbagai makhluk gaib untuk mencari penyebab seseorang jatuh sakit. Adapun untuk mengobati pasiennya, dia menggunakan media kemenyan dan panglay. Kedua media tersebut diberi doa-doa dan mantra oleh dukun, kemudian diserahkan kepada pasien berikut pesan agar melaksanakan suatu ritual terkait dengan kedua media tadi di rumahnya masing-masing.

Kemenyan harus dibakar dan dipasang di tempat-tempat tertentu, dan panglay dikunyah lalu disemburkan ke tempat-tempat tertentu pula. Tujuan dari ritual tersebut tak lain untuk 
mendamaikan seluruh anggota keluarga di dalam rumah itu dengan kekuatan gaib yang merasa terganggu; juga mengusir kekuatan gaib yang memang telah dan hendak mengganggu penghuni rumah tersebut.

Dukun seringkali kedatangan warga Kasepuhan Cipta Mulya yang menderita sakit secara fisik maupun mental di rumahnya sendiri. Selain itu, dia juga kerap menerima undangan dari warga yang ingin diobati di rumahnya masing-masing. Untuk memenuhi undangan tersebut, dia sering berkeliling dari kampung satu ke kampung lain yang di dalamnya terdapat warga Kasepuhan Cipta Mulya. Sebagai ucapan terima kasih karena telah ditolong, warga biasanya memberi beras atau uang sesuai kemampuannya masing-masing. Selain medapat imbalan dari warga kasepuhan, dia mendapat tunjangan sejumlah pocong padi dari ketua adat. Pemberian tunjangan tersebut dilakukan dalam kurun waktu tertentu.

Ada kalanya warga mengalami sakit yang berkepanjangan, sekalipun kedua cara pengobatan tersebut telah dilakukan. Jika hal itu terjadi, upaya pengobatan terakhir akan diserahkan kepada ketua adat. Dalam hal ini, ketua adat akan mencoba mencari penyebabnya. Umumnya hal itu terjadi karena ada janji-janji atau semacam nadar yang belum dilaksanakan oleh yang bersangkutan. Oleh karena itu, ketua adat menyarankan agar yang bersangkutan segera melaksanakan janjijanji tersebut.

Tugas dukun yang berikutnya adalah menyiapkan bahan baku untuk membuat sawen 'gabungan atau kesatuan dari beragam tanaman dan bahan-bahan lainnya yang berfungsi sebagai penolak bala'. Bahan-bahan tesebut terdiri atas tulak tanggul, pacing, sulangkar, palias, rane, kupat 'ketupat', harupat, leupeut, dan tangtang angin. Agar bisa berfungsi sebagai penolak bala, semua bahan tersebut disatukan menjadi sawen dan disertakan dalam satu upacara tradisional tertentu. Setelah itu, sawen biasanya dipasang di tempat-tempat tertentu milik seluruh warga Kasepuhan Cipta Mulya, baik yang tinggal di dalam maupun di luar Kampung Cipta Mulya. Tempat menyimpan sawen biasanya di atas pintu rumah dan pintu kandang ternak.

\section{c. Gandek}

Gandek adalah seseorang yang mendapat tugas dari ketua adat untuk menjadi pengawal pribadinya. Sebagai seorang pengawal pribadi, dia harus lakilaki yang memiliki sifat cerdas, kuat, cekatan, jujur, sabar, setia, dan selalu siap kapanpun dibutuhkan oleh ketua adat. Melihat karakternya yang seperti itu, tentu tidak mudah bagi ketua adat mengangkat seseorang untuk menjadi gandek.

Sifat-sifat yang dibutuhkan sebagai seorang gandek biasanya akan ditemukan pada orang-orang yang memiliki darah gandek juga dari leluhurnya. Itu artinya, jabatan tersebut memang didapat secara turun temurun. Jika seseorang telah mendapat waris leluhur untuk menjadi seorang gandek, secara adat dia memiliki kewajiban untuk melaksanakan tugas tersebut. Dia tidak dapat menolaknya, karena penolakan akan membuatnya dibendon 'mengalami berbagai hal yang tidak menguntungkan, seperti sakit yang berkepanjangan atau jauh dari keberkahan hidup'. Jabatan gandek hanya dimiliki 
oleh satu orang, dengan masa jabatannya berlangsung seumur hidup.

Sebagai seorang gandek, dia mengetahui betul jadwal kegiatan sehari-hari ketua adat. Oleh karena itu, dia harus menyiapkan berbagai hal yang diperlukan ketua adat dalam rangka menjalankan tugasnya. Jika ketua adat pergi, dipastikan dia akan selalu menemaninya. Yang tampak khas dari seorang gandek pada saat mendampingi ketua adat pergi ke suatu tempat adalah senantiasa membawa tas kaneron.

\section{d. Bengkong}

Warga Kasepuhan Cipta Mulya seluruhnya beragama Islam. Oleh karena itu, setiap anak laki-laki yang sudah cukup umur wajib dikhitan. Khitanan di wilayah Cipta Mulya biasanya dilaksanakan secara massal bagi anak laki-laki berusia antara 5 sampai dengan 8 tahun. Meskipun demikian, jika ada warga yang tidak ingin bergabung dalam acara khitanan massal, dia dapat melaksanakannya sendiri.

Petugas adat yang bertanggung jawab terhadap pelaksanaan khitanan massal atau individu di Kasepuhan Cipta Mulya disebut bengkong. Khitanan massal atau acara kendurian lainnya biasanya dilaksanakan setelah panen, khususnya usai diselenggarakan upacara Seren Taun.

Bengkong adalah sebutan yang diberikan kepada seseorang yang memiliki kemampuan mengkhitan anak laki-laki dan mengurus berbagai hal lainnya terkait dengan pekerjaan tersebut. Seorang bengkong biasanya laki-laki. Dia mendapat jabatan tersebut secara turun temurun, dengan masa jabatannya berlangsung seumur hidup. Jumlah bengkong di Kasepuhan Cipta Mulya hanya ada satu.

Sat ini, semakin sedikit warga Kasepuhan Cipta Mulya yang memanfaatkan jasa bengkong untuk mengkhitan anak laki-lakinya. Mereka ternyata lebih memilih pergi ke petugas medis ketika akan mengkhitan anak laki-lakinya. Sekalipun demikian, tidak berarti bengkong ditinggalkan oleh warga Kasepuhan Cipta Mulya. Mereka tetap menghargai dan menghormati kedudukan seorang bengkong. Hal itu tampak dari kedatangan mereka ke rumah bengkong, sebelum anak laki-lakinya dikhitan oleh tenaga medis. Kedatangan mereka untuk meminta doa dan sekaligus melaksanakan ritual adat agar acara khitanan berlangsung lancar dan selamat. Orang tua yang akan mengkhitan anaknya datang sambil membawa perlengkapan berupa beras, kue, pisang, dan uang. Perlengkapan tersebut diberikan kepada bengkong.

\section{e. Paraji}

Ada dua jenis paraji di Kasepuhan Cipta Mulya, yakni parajingalahirkeun danparajipanganten.Parajingalahirkeun adalah sebutan yang ditujukan kepada seorang wanita yang mendapat tugas dari ketua adat untuk menangani ibu hamil, membantu persalinan dan pasca persalinan, serta merawat bayinya di Kasepuhan Cipta Mulya. Termasuk dalam pekerjaan tersebut adalah memimpin pelaksanaan ritual adat di seputar kehamilan dan persalinan.

Paraji panganten merupakan sebutan bagi seorang wanita yang mendapat tugas dari ketua adat untuk mengurusi pasangan yang akan menikah, dari persiapan, saat pernikahan 
berlangsung, hingga usai pernikahan. Dia menyiapkan berbagai perlengkapan yang akan digunakan oleh kedua mempelai, serta memimpin ritual adat di seputar perkawinan.

Jumlah paraji ngalahirkeun dan paraji panganten di Kasepuhan Cipta Mulya masing-masing satu orang. Jabatan tersebut diperoleh secara turun temurun dari leluhurnya. Agar dapat melaksanakan tugasnya, keduanya harus mendapat restu dan legitimasi dari ketua adat. Dari pekerjaannya sebagai parajingalahirkeun dan paraji panganten, mereka mendapat imbalan berupa beras, makanan, bahkan juga uang sebagai ungkapan terima kasih dari warga.

\section{f. Pamoro}

Pamoro adalah sebutan bagi warga Kasepuhan Cipta Mulya yang memiliki kemampuan berburu binatang. Seorang pamoro biasanya laki-laki dewasa, yang mendapat ilmu berburu dari lingkungan keluarganya yang berdarah pamoro dari leluhurnya. Ada sekitar 25 orang pamoro di Kasepuhan Cipta Mulya, dan hanya sekitar 12 orang yang dapat dikatakan benar-benar ahli dalam berburu. Salah satu di antaranya diangkat sebagai pimpinan pamoro, yang dipilih berdasarkan pertimbangan senioritas, keahlian berburu, pengalaman berburu, dan tentu saja mendapat legitimasi ketua adat.

Ketika hendak pergi berburu, pimpinan pamoro terlebih dulu datang kepada ketua adat untuk meminta izin dan doa. Tentu saja dia tidak akan bekerja sendiri melainkan senantiasa tergabung dalam satu kelompok. Setiap berburu, jumlah anggota kelompoknya antara 12 (dua belas) sampai dengan 25 (dua puluh lima) orang, itupun dilakukan secara bergantian. Selain itu, mereka juga ditemani sejumlah anjing yang terlatih untuk membantu mereka pada saat berburu. Tak lupa perlengkapan berburu juga dibawa, seperti tombak, senapan, golok, pisau, tali, juga bekal makanan.

Para pamoro dapat berburu pada hari-hari Senin, Selasa, Rabu, Kamis, atau Sabtu. Pilihan hari biasanya berdasarkan kesepakatan mereka sendiri. Mereka berangkat pukul 07.00 WIB dan biasanya kembali pada pukul 17.00 WIB. Wilayah berburu mereka adalah area huma'lahan pertanian kering' dan sekitarnya yang terdapat di sejumlah bukit, seperti Pasir Awi, Pasir Toloktok, dan Pasir Engang

Ada dua tugas utama yang harus dilakukan oleh kelompok pamoro. Pertama, mereka menjaga tanaman di ladang dari serangan hama berupa jedut 'babi hutan' dan kera. Penjagaan lebih intensif dilakukan menjelang panen. Bila perlu, hama seperti itu diburu dan dibunuh, namun hasil buruannya bukan untuk dikonsumsi. Kedua, mereka mendapat tugas mencari lauk pauk untuk keperluan upacara seren taun dan nganyaran. Binatang yang dicari adalah kijang. Cukup sulit bagi mereka untuk berburu kijang, meskipun demikian mereka tetap berusaha. Ada kalanya mereka berhasil, dan seringkali mereka juga gagal mendapatkan kijang.

Jika mereka berhasil mendapat kijang, tentu mereka akan merasa senang dan puas. Sebagian hasil buruannya digunakan untuk keperluan makan bersama dalam kegiatan upacara seren taun atau nganyaran, dan sebagian lagi menjadi jatah para pamoro. Di luar kedua tugas utama tadi, para pamoro bebas berburu kapan saja untuk 
menyalurkan kegemaran mereka. Para pamoro mendapat jabatan tersebut secara turun temurun atau merupakan wasiat dari orang tuanya agar meneruskan pekerjaan sebagai pamoro. Jika dia tidak menerima jabatan tersebut, diyakini akan mengakibatkan hal-hal yang buruk menimpa mereka.

\section{g. Panghulu}

Panghulu adalah salah satu jabatan adat yang terdapat dalam jajaran baris sesepuh di Kasepuhan Cipta Mulya. Jabatan tersebut dipegang oleh lakilaki, yang jumlahnya hanya satu orang. Dia memiliki pengetahuan yang cukup mendalam tentang agama Islam. Oleh karena itu, tugas dia di Kasepuhan Cipta Mulya berhubungan erat dengan pengetahuan yang dimilikinya.

Beberapa tugas yang harus dilaksanakan oleh seorang panghulu di antaranya adalah memimpin doa kepada Tuhan dan mengirim hadiah doa kepada leluhur dalam berbagai acara adat dan perayaan hari-hari besar Islam. Kegiatan adat yang dimaksud, seperti dari upacara ngaseuk hingga seren taun dan berziarah ke makam leluhur; sedangkan perayaan hari besar Islam yang dimaksud di antaranya muludan dan rajaban. Dia juga biasa diminta bantuan mengurus jenazah, dari memandikan hingga menguburkan jenazah. Selain itu, dia kerap diminta jasanya untuk menyembelih hewan ternak milik warga, seperti ayam, kambing, dan kerbau.

Tugas lainnya yang harus dikerjakan oleh seorang panghulu adalah mengelola kegiatan yang berlangsung di langgar. Ada sebuah langgar di pusat Kasepuhan Cipta Mulya, yang bangunannya tidak jauh berbeda dengan rumah-rumah adat yang terdapat di tempat tersebut. Kelangsungan aktivitas di langgar diserahkan kepada panghulu. Salah satu kegiatan yang berlangsung di tempat itu adalah pengajian untuk anakanak yang berjumlah sekitar 100 orang, di bawah bimbingan panghulu. Untuk jasa dia mengajar membaca alquran kepada anak-anak, para orang tua secara sukarela memberi beras atau uang semampunya.

Seorang panghulu memperoleh jabatannya secara turun temurun. Jika salah seseorang dari keturunan panghulu mendapat waris untuk menjadi panghulu dari orang tuanya, dia tak dapat menolaknya karena takut dibendon. Oleh karena itu, dengan penuh keikhlasan serta tanggung jawab dia akan melaksanakan tugas tersebut sampai dia meninggal atau merasa sudah tak mampu lagi mengeban tugas tersebut.

\section{h. Giliran}

Giliran adalah sebutan bagi perempuan yang mengabdikan dirinya untuk membantu pekerjaan rumah tangga di tempat tinggal ketua adat. Dia bersedia menjadi giliran karena mendapat amanat dari ibunya yang juga menjadi giliran, agar kelak meneruskan pekerjaan ibunya. Itu artinya, jabatan adat sebagai giliran diwariskan secara turun temurun. Pada saatnya nanti, dia harus melaksanakan tugas tersebut. Kalau tidak, dia akan dibendon sehingga kehidupannya jauh dari keberkahan.

Saat ini ada 8 orang perempuan yang menjadi giliran. Umumnya, mereka sudah berkeluarga. Jarang sekali ada generasi muda yang bersedia menjadi anggota giliran. Umumnya, perempuan muda lebih memilih untuk bekerja di kota. Kalaupun waris itu jatuh kepada 
dia, tugas tersebut akan dijalaninya kelak setelah dia berkeluarga.

Kedelapan giliran tadi tidak bekerja dalam waktu yang bersamaan, melainkan dibagi dalam 4 sif oleh ketua Rukun Tetangga (RT). Jadi, dalam satu sif terdapat 2 giliran dan bekerja selama dua hari. Misalnya, jika jadwal datang pada Minggu sore maka jadwal pulangnya pada Selasa sore. Pada saat bekerja, giliran akan membawa serta suami dan anak-anaknya. Pengaturan jadwal kerja seperti itu dilakukan agar mereka dapat mengabdi kepada ketua adat tanpa harus meninggalkan pekerjaan mereka, yakni menggarap sawah dan huma, menyadap aren, atau membuat gula merah.

Tugas giliran adalah membantu menyelesaikan pekerjaan rumah tangga, seperti memasak, mencuci piring, melayani tamu, membersihkan rumah dan halaman rumah. Umumnya, giliran dan keluarganya akan menginap di rumah ketua adat, selama dua hari bekerja. Jika rumah giliran dekat dengan kediaman ketua adat, dia bisa pulang dulu ke rumahnya. Namun hal itu agak sulit dilakukan pada saat banyak tamu di rumah ketua adat, karena tentu saja lebih banyak pekerjaan yang harus diselesaikan. Pada saat-saat seperti itu, anggota giliran yang bekerja bisa lebih dari dua orang, bergantung pada volume pekerjaannya.

Selesai melaksanakan tugas di rumah ketua adat, giliran pulang membawa bekal nasi dan lauk-pauk dari isrti ketua adat, bahkan kadang-kadang juga diberi uang. Khusus ketika upacara seren taun tiba, giliran akan mendapat jatah berupa kain panjang dan kebaya dari istri ketua adat.

\section{i. Kemit}

Kemit merupakan sebutan bagi laki-laki yang mendapat tugas untuk menjaga keamanan tempat tinggal ketua adat di lingkungan imah gede. Tempat tersebut dijaga dari berbagai hal yang dapat mengganggu keharmonisan dan kenyamanan lingkungan fisik berikut para penghuninya. Penjagaan tersebut dilakukan sepanjang siang dan malam oleh kemit. Oleh karena itu, ketua adat menyediakan satu ruangan khusus untuk para kemit. Lokasinya menyatu dengan imah gede.

Ada 14 (empat belas) orang kemit di Kasepuhan Cipta Mulya, yang semuanya laki-laki. Mereka menerima jabatan tersebut secara turun temurun, dan masa jabatannya berlangsung sampai mereka meninggal atau sampai mereka tidak mampumelaksanakantugasnya. Keempat belas kemit tadi dibagi dalam beberapa kelompok, dengan jumlah anggota dua orang untuk setiap kelompoknya. Jadwal bertugas setiap kelompok adalah dua hari dua malam. Selama bertugas menjaga keamanan imah gede, mereka selalu waspada terhadap orang baru yang masuk ke wilayah mereka dan berbagai hal yang dapat membahayakan keamanan mereka.

Pada saat berada di lingkungan imah gede, kemit juga mengerjakan tugas lainnya. Mereka bertanggung jawab terhadap beberapa kebutuhan logistik tertentu. Mereka harus mencari kayu bakar untuk kebutuhan memasak, dan menyiapkan daun pisang untuk keperluan dapur di rumah ketua adat. Selain itu, mereka biasanya ikut membersihkan halaman rumah ketua adat yang cukup luas. 


\section{j. Amil}

Amil merupakan sebutan bagi seorang laki-laki yang bertugas menikahkan sepasang calon pengantin agar sah menurut aturan pemerintah dan tercatat secara resmi di Kantor Catatan Sipil. Dengan demikian, kewajiban dan hak-haknya sebagi suami istri benarbenar jelas dan tegas.

\section{Warga Komunitas Adat Kasepuhan Cipta Mulya}

Warga komunitas adat Kasepuhan Cipta Mulya adalah mereka yang menginduk pada adat istiadat dan tradisi di Kasepuhan Cipta Mulya. Mereka yang menjadi warga kasepuhan tersebut tidak hanya tinggal di Kampung Cipta Mulya, melainkan juga tersebar di sejumlah kampung lainnya. Saat ini, ada sekitar 12.383 jiwa tercatat sebagai warga Kasepuhan Cipta Mulya, yang terbagi menjadi 2.203 kepala keluarga. Warga Kasepuhan Cipta Mulya terbagi lagi dalam sejumlah rendangan 'satu kesatuan keluarga yang berasal dari satu keturunan yang sama'. Setiap rendangan biasanya beranggotakan lebih dari satu keluarga.

Seluruh warga Kasepuhan Cipta Mulya, baik yang tinggal di dalam maupun di luar Kampung Cipta Mulya, memiliki kewajiban untuk patuh kepada pimpinan mereka, yakni ketua adat. Mereka harus berbakti, menghormati, mendengarkan nasihat, mengikuti perintah, dan menjauhi segala larangannya. Semua itu tentu dalam konteks yang berhubungan dengan adat istiadat Kasepuhan Cipta Mulya.

Warga Kasepuhan Cipta Mulya harus senantiasa memegang teguh dan melaksanakan apa yang telah diwariskan leluhurnya. Setiap langkah mereka dalam kehidupan sehari-hari, selalu mengacu pada adat istiadat Kasepuhan Cipta Mulya. Keteguhan seperti itu dipercaya akan mendatangkan keberkahan bagi mereka, karena segala sesuatunya mendapat restu ketua adat. Restu dari ketua adat sama dengan mendapat restu dari leluhur, karena dia merupakan perwakilan leluhur di dunia. Sebaliknya, ketua adat akan merasa prihatin kepada warganya yang meninggalkan atau jauh dari adat istiadat kasepuhan. Hal itu akan membuat hidup dia senantiasa jauh dari segala keberkahan.

Warga Kasepuhan Cipta Mulya yang tinggal di pusat kasepuhan, yakni di Kampung Cipta Mulya, lebih memungkinkan untuk mengekspresikan adat istiadat dalam berbagai aspek kehidupan secara total. Setiap saat mereka bisa datang meminta berkah kepada ketua adat atas segala niatan untuk melakukan aktivitas penting. Mereka dapat mengikuti dan melaksanakan semua aktivitas adat yang dilakukan di Kasepuhan Cipta Mulya. Dengan demikian, secara berkesinambungan mereka senantiasa berada di lingkungan sosial yang memelihara adat istiadat Kasepuhan Cipta Mulya.

Kesadaran itu akan selalu terjaga karena ada pengendalian dan pengawasan langsung dari ketua adat beserta jajarannya. Sekali saja warga melanggar aturan adat, mereka harus berhadapan langsung dengan ketua adat dan lingkungan sosialnya. Mereka akan mendapat sanksi sosial dari lingkungan masyarakatnya, digunjingkan misalnya. Selain itu, mereka dipastikan mendapat teguran dari pemimpin adat agar kembali mematuhi adat istiadat setempat.

Berbeda halnya dengan warga yang berada jauh dari pusat Kasepuhan 
Cipta Mulya, cukup sulit untuk berperilaku total seperti itu. Secara individu, mereka merasa sebagai bagian dariwarga Kasepuhan Cipta Mulya. Jika memungkinkan, dia akan berupaya melakukan komunikasi dengan ketua adat agar mendapat berkah dalam kehidupannya. Jika tidak memungkinkan, mereka bisa datang kepada kolot lembur. Dia merupakan perpanjangan tangan ketua adat di luar Kampung Cipta Mulya. Oleh karena itu, dia dapat memutuskan segala sesuatu yang berhubungan dengan adat. Tentu saja semua itu atas izin dari ketua adat di Kampung Cipta Mulya.

Secara sosial, mereka memiliki keterbatasan untuk senantiasa terlibat dalam semua aktivitas yang bernuansa adat di pusat Kasepuhan Cipta Mulya. Sekalipun begitu, mereka tetap berupaya untuk berpartisipasi di dalamnya, baik dengan memberi sumbangan. atau terlibat langsung dalam kegiatan tersebut. Paling tidak, ada satu kesempatan yang sangat jarang dilewatkan oleh mereka, yakni mengikuti upacara seren taun.

Ribuan warga kasepuhan datang ke acara yang paling besar di pusat Kasepuhan Cipta Mulya. Kedatangan mereka untuk mengekspresikan beberapa hal penting, di antaranya mereka ingin membuktikan dirinya sebagai bagian dari warga Kasepuhan Cipta Mulya; mereka juga mengharapkan berkah yang melimpah dari upacara tersebut; mereka memanfaatkan kesempatan tersebut untuk saling bersilaturahim satu sama lainnya; dan mereka juga ingin menunjukkan rasa baktinya kepada ketua adat dan leluhurnya.

\section{PENUTUP}

Lembaga adat adalah sebuah organisasi sosial kemasyarakatan, baik yang sengaja dibentuk maupun yang secara wajar telah tumbuh dan berkembang di dalam sejarah masyarakat yang bersangkutan atau dalam suatu masyarakat hukum adat tertentu dengan wilayah hukum dan hak atas harta kekayaan di dalam wilayah hukum adat tersebut serta berhak dan berwenang untuk mengatur, mengurus, dan menyelesaikan berbagai permasalahan yang berkaitan dengan dan mengacu pada adat istiadat dan hukum adat yang berlaku (Depdikbud, 2001:7).

Lambaga adat yang terdapat di Kasepuhan Cipta Mulya disebut kasepuhan, yang mengacu pada aturan adat warisan leluhur yang mengatur tata kehidupan warga Kasepuhan Cipta Mulya sampai saat ini. Lembaga adat itu mengatur kedudukan seseorang dalam masyarakat di Kasepuhan Cipta Mulya. Hal itu tercermin dalam struktur organisisi lembaga adat tersebut, yang mengacu pada penguasaan adat istiadat setempat.

Dalam struktur organisasi lembaga adat kasepuhan, secara hierarkis ditempatkan kedudukan seseorang dalam kehidupan masyarakat di Kasepuhan Cipta Mulya. Kedudukan yang paling tinggi ditempati oleh seorang ketua adat. Dia adalah pemimpin Kasepuhan Cipta Mulya, dengan segala kewajiban yang harus dilaksanakannya serta hak-hak yang akan diterimanya. Kedudukan berikutnya ditempati oleh jajaran baris sesepuh, yang terdiri atas sejumlah orang tertentu. Mereka diberi tugas khusus oleh ketua adat, yang berbeda satu sama lainnya. Para sesepuh itu merupakan orang-orang pilihan yang akan membantu ketua adat dalam menjalankan tugasnya. Kedudukan yang berikutnya ditempati oleh warga Kasepuhan Cipta Mulya, baik 
yang tinggal di dalam maupun di luar Kampung Cipta Mulya.

Kasepuhan Cipta Mulya merupakan aset yang begitu bernilai bagi masyarakat juga pemerintah Jawa Barat, khususnya Kabupaten Sukabumi. Mereka merupakan salah satu komunitas adat di Kabupaten Sukabumi yang memiliki keunikan tersendiri, yakni melestarikan budaya Sunda. Oleh karena itu, keberadaan mereka perlu mendapat perhatian dari berbagai pihak, termasuk pemerintah agar senantiasa mendapat ruang untuk mengekspresikan adat istiadat mereka.

\section{DAFTAR PUSTAKA}

Adimiharja, Kusnaka. 1983.

Kerangka Studi Antropologi

Sosial dalam Pembangunan.

Bandung: Tarsito.

1992.

Kasepuhan yang Tumbuh di Atas yang Luruh. Bandung:Tarsito.

BPSNT Bandung. 2001.

Desain Penelitian dan Pengkajian. Bandung: BPSNT Bandung

Manan, Fadjria Novari. 2004.

Sistem Kemasyarakatan. Disampaikan dalam Seminar Kebudayaan Daerah Sistem Kawargian Orang Sunda. Bandung: BPSNT Bandung.

Meinanda, Teguh dan D.Akhmad. 1981.

Tanya Jawab Pengantar Antropologi. Bandung: CV. Armico.
Sanit, Arbit. 1984.

Sistem Politik Indonesia. Jakarta: Rajawali.

Shm., Suhandi. 1991.

Pola Hidup Masyarakat Indonesia. Bandung: Jurusan Antropoloanggi UNPAD

Soekanto, Soerjono.1982.

Sosiologi Suatu Pengantar. Jakarta: Rajawali 1983.

Beberapa Teori Sosiologi tentang Struktur Masyarakat. Jakarta: Rajawali.

Suhada. 2003.

Masyarakat Baduy dalam Rentang Sejarah. Banten:Dinas Pendidikan Provinsi Banten. 